me. As it stretched its legs backwards the yellow feet contrasted sharply with the dark legs, positively identifying it as a Snowy Egret.

Editor's Note: Miss Joyce Gunn writes that this bird was seen for a week (May 23-29) near their buildings. She claims that it was not as much afraid of people as the four birds which came in to feed May 24. These four varied from patchy blue to a very dark blue but they flew at the first sight of man. Miss Gunn is positive that these were the Little Blue Heron.

These reports are confirmed, for the Snowy Egret was also seen in the Qu'Appelle Valley east of Craven. Mr. E. Fox and Mrs. A. Swanston saw its yellow feet clearly on July 9 as it stood on the roadway crossing the flooded valley. The Snowy Egret was seen several times near where the American Egret nests.

\title{
Saskatchewan's First Parula Warbler
}

\author{
By E. MANLEY CALLIN, Fort San, Sask.
}

On May 31, 1956, I was astounded to discover and have a long visit with a male Parula Warbler as it was feeding and singing steadily in a small grove of trees on the grounds of the Fort Qu'Appelle Santorium.

At about 11 a.m. I was walking by the grove and heard an unfamiliar song. The songster was easy to find

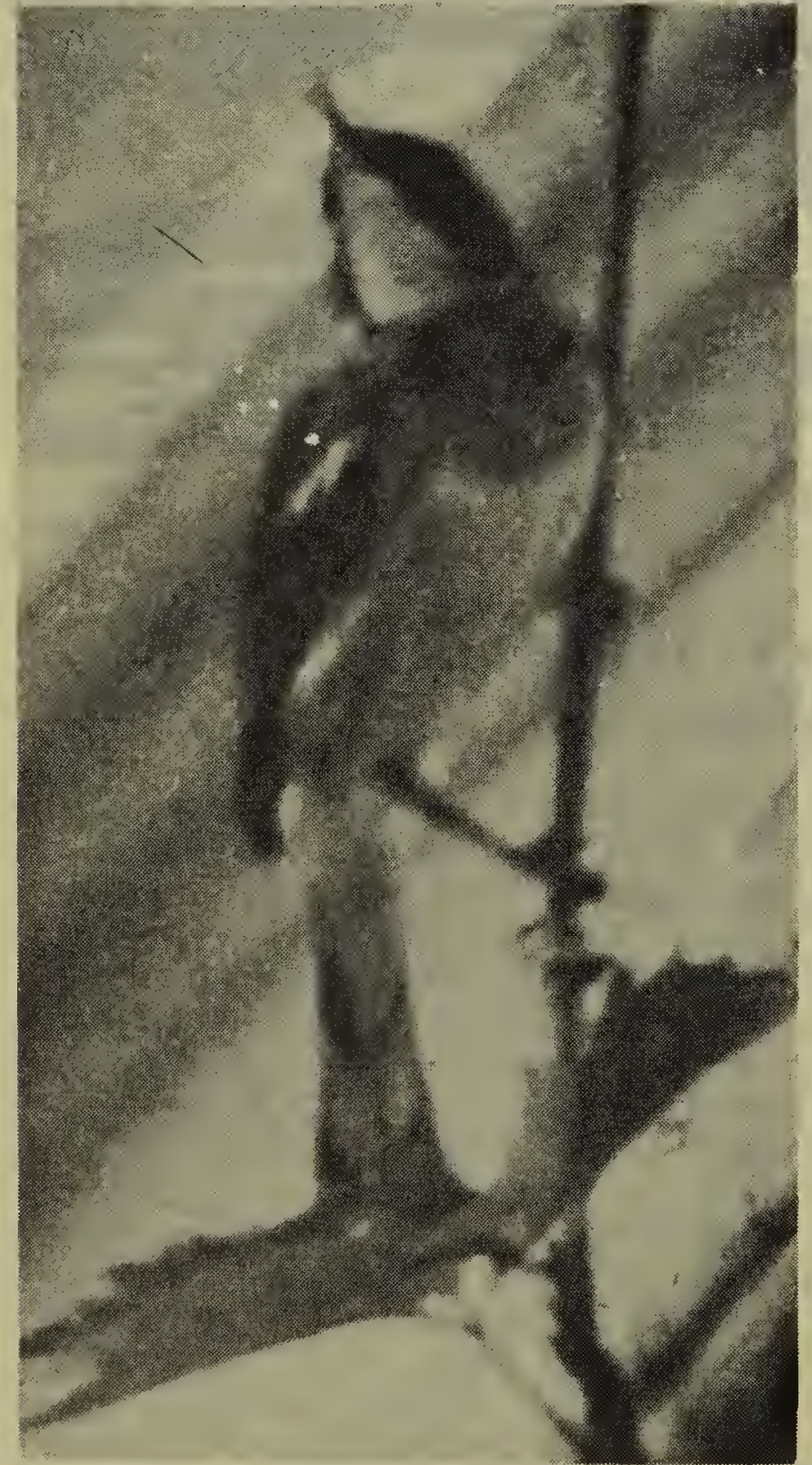

Photo from a Kodachrome by F. W. Lahrman

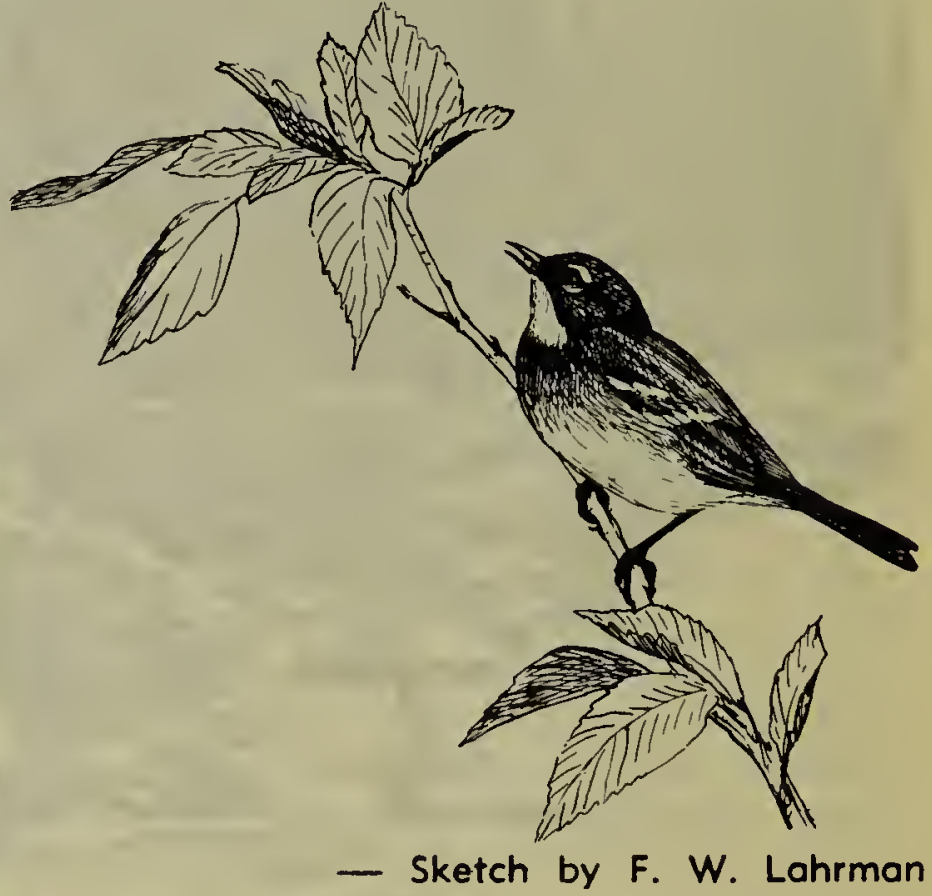

but was moving very briskly among the higher branches of the poplars and conifers, making observation very difficult. Even when it moved to the lower branches it was so active that it took some time to identify the bird. I watched the bird most of the time from 11 a.m. to 1:45 p.m. and it sang and fed steadily, working its way from one end of the grove to the other a number of times. At 1:45 it became silent and disappeared and was not seen or heard again. although I returned three times to listen. I thought that it might have moved on but at 10:30 a.m. on June 1 it was heard again. I, therefore, contacted Mr. Fred Bard, Director of the Provincial Museum at Regina, and he arranged for two of his staff to come out and take a series of color pictures. The bird behaved admirably and a number of pictures verify my identification, a black and white reproduction of one of these is shown below. 
After the second day the bird expanded its territory and became even more vocal. It moved through the other groves and among the private residences where it climbed over the vines and trellises, singing and affording almost arm's length views of its beautiful coloring. All day long it could be seen flitting about, examining minutely every part of the territory from the ground to the top of the tallest trees: flower beds, vines, trellises, ledges, telephone poles, telephone wires.

And all day long it would sing its unmusical but pleasing and distinctive songs. What we might call its No. 1 song: The one it rendered the most-was a dry trill risingin pitch and increasing in tempo, then ending very suddenly in a very emphatic and buzzy note. It might be described as follows: Cheweechewee - chi - chi - chi - chi - chi zh. Song No. 2 was rendered sparingly: only once did I hear it used more than a dozen times in succession. This song was usually three buzzy notes followed by the same dry trill as in song No. 1. Song No. 2 might, be described as follows: Zwee-zweechi - chi - chi - chi - chi.

It is difficult to imagine what brought this eastern warbler so far out of its normal range. It is a new addition to the Saskatchewan check list but on the present evidence it must be placed in the accidental category. No female was seen and nesting did not occur in this area. For eight days this beautiful male Parula Warbler graced our premises. We heard it last at 8:30 p.m. on June 7, 1956.

\title{
Say's Phoebe in Saskatchewan
}

\author{
By FRANK H. BRAZIER, Regina
}

According to P. A. Taverner (Birds of Canada, 1934) Say's Phoebe (Sayornis saya) is found in "Western North America from central Alaska and Mackenzie south to New Mexico. In Canada, east to southwestern Manitoba, where it seems to be a comparatively recent arrival." This is a bird of the arid areas of the West; hot, dry gulches, desolate mountain sides, as well as barns and outbuildings are typical haunts. One would expect it to be generally distributed throughout southern Saskatchewan prairies, but so far as I can find there is no published record of the bird's occurrence in Saskatchewan farther east than Regina, although southwestern $\mathrm{M}$ a nito b a (Turtle Mountains) is within its range (Taverner, op. cit.).

Say's Phoebe is a $7 \frac{1}{2}$ inch flycatcher, with grey-brown back, slightly darker head, and dark brick or rusty ochre underparts. Look for a bird a little larger than a House Sparrow, with a black tail and yellowish or reddish belly, grey breast, and the typical habits of a flycatcher. It occurs quite commonly in Regina, and seems to be increasing here. Between the years 1947-1953 I recollect only the one pair which nested annually in our neighborhood. One arrived each April 17th for
1953, 1954 and 1955 but as it was cold and snowy that date in 1956 it did not show up until noon, April 19. In 1955 I observed 10 birds in Regina including the pair with its four young in the backyard. This year (1956) I have seen 15 individuals in widely separated areas in the south half of Regina, including the home pair with three young. Mrs. H. F. Tempel reports a pair nesting for six years in the porch at 17 Ingersoll Crescent, Regina, in spite of the four busy boys of the house. Mrs. Tempel also reports a pair nesting in the 2600 block Atkinson Street. These birds avoid the trees and rest on posts, wires or house tops.

In a recent survey $\mathrm{Mr}$. and Mrs. Harry Flock (Regina), Mr. P. Laurence Beckie (Bladworth), Mr. Steve Mann (Skull Creek), and Mr. John Walker (Moose Jaw), all record Sayornis saya. Mr. Mann adds that while the bird still breeds commonly in his area, its numbers have gone down in recent years. Mr. Frank Baines (Saltcoats), Mrs. Ann Olson (Big River), Mr. Stuart Francis (Torch River), Mr. Maurice Street (Nipawin), Messrs. Ronald a n d Donald Hooper (Somme), Mr. William Niven (Sheho), Messrs. A. Wilson and W. Jasper (Struan), and W. Yanchinski (Naicam) do not re- 